\title{
6. Subnational debt: developing a sustainable market
}

\section{Lili Liu' ${ }^{1}$}

\section{INTRODUCTION}

The importance of subnational debt market is driven primarily by decentralization and the immense needs of financing infrastructure. The responsibility for urban infrastructure investments and operations has been increasingly decentralized to subnational governments (SNGs) in many countries. ${ }^{2}$ The massive scale of urbanization requires infrastructure investment (such as in power, water, sanitation, roads, airports, schools, and hospitals) to absorb the influx of rural populations (Liu and Tan 2009). "Developing Asia will need to invest \$1.7 trillion per year in infrastructure until 2030 to maintain its growth momentum, tackle poverty, and respond to climate change" (ADB 2017). Allowing SNGs to access financial markets for financing infrastructure has thus become a policy focus in many countries.

There are public policy benefits for SNGs to access financial markets for infrastructure financing. As noted by Liu and Waibel (2008a), borrowing enables SNGs to capture the benefits of major capital investments immediately, rather than wait to accumulate savings from current income. Subnational borrowing also finances infrastructure more equitably across multigenerational users of infrastructure services because debt maturity can match the economic life of the assets being financed, and the beneficiaries can pay for the services.

For a long time, bank lending and central government onlending were the only forms of credit supplied to SNGs, but many countries in recent years have started to experiment with allowing SNGs to access capital markets. ${ }^{3}$ Bank loans tend to have much shorter maturities (except some policy loans from government development banks). In contrast, bond instruments can better match the maturity of the debt service with the life span of the infrastructure assets being financed.

Compared with bank loans, bond instruments can enforce financial and governance transparency of borrowers, as credit ratings are a precondition for borrowers (bond issuers). A competitive bond issuance process can differentiate risk premiums for borrowers according to their different financial strengths, thus more effectively acting as an intermediary between savers (credit suppliers) and borrowers (debtors). It can also build on the existing sovereign and corporate bond market, to further strengthen securities market institutions, such as rating agencies, dealers, auditors, and trusts, as well as to diversify the investor base by attracting mutual funds, life insurance, pensions, and individual investors.

Macroeconomic challenges from COVID-19 may have added momentum to the expansion of SNG borrowing. Economic disruptions would reduce SNG revenues, as SNGs in many 
countries rely heavily on fiscal transfers. The main sources of fiscal transfers are value-added tax and corporate and personal income taxes, all of which are cyclical. For resource-rich countries, a significant portion of fiscal transfers comes from volatile commodity-export revenues.

Notwithstanding the demand for, and benefits of, SNG borrowing, history is replete with subnational default risks. The 1990s saw widespread subnational debt crises:

To many observers, runaway provincial debt in Mendoza and Buenos Aires was a major factor behind Argentina's sovereign debt default in 2001. Brazil experienced two subnational debt crises following the early one in the 1980s. The 1995 Tequila crisis in Mexico exposed the vulnerability of subnational debt to the peso devaluation and led many Mexican subnationals into debt crisis. In Russia, at least 57 of 89 regional governments defaulted from 1998 to 2001 (Liu and Waibel 2008b, p. 216).

As noted by Liu and Waibel (2008b), even without explicit defaults, fiscal stress and implicit liabilities are a real concern. In India, many states experienced fiscal stress in the late 1990s, with fiscal deficits, debt, and contingent liabilities increasing rapidly. SNGs in Colombia, Hungary, and South Africa also experienced fiscal stress in the 1990s.

This chapter focuses on the challenges of developing subnational debt markets, which involve issues relating to the intergovernmental finance system that will impact the subnational borrowers' capacity and credit strength to borrow, and market institutional infrastructure that will impact the depth, liquidity, and cost of credit supply. Financial discipline for both borrowers and creditors is intertwined with these supply and demand challenges. Managing macroeconomic stability, particularly in times of crisis, also adds to the challenges, because a sovereign's macroeconomic fundamentals largely determine the fiscal and debt dynamics of SNGs (Liu and Tan 2009).

The rest of the chapter is structured as follows. Section 2 reviews the development of subnational debt markets in select middle-income countries in the Asian region. Section 3 discusses regulation of subnational debt in the context of common pool problems and key elements of the intergovernmental fiscal system, including the importance of incorporating SNG annual deficit and debt targets in the overall fiscal and net borrowing of the public sector. Section 4 reviews thematic issues of the intergovernmental fiscal system, debt restructuring, and off-budget liabilities that have an important bearing on subnational borrowing. Section 5 discusses the importance of macroeconomic frameworks to SNG debt sustainability. Section 6 concludes.

\section{SUBNATIONAL DEBT MARKET DEVELOPMENT}

Developing a sustainable subnational debt market is a long-term challenge in many countries. Bank loans continue to be the main source of credit supply. Subnational securities markets are mostly small in scale and lack liquidity and secondary markets. But in India and the People's Republic of China (PRC) reforms have led to significant progress in developing subnational bond markets.

It will be useful to start the section with a quick look at the experience of the United States (US), as it has the longest history of developing subnational debt markets, and its gradual and incremental reforms offer valuable lessons to other countries.

The US has large, liquid and competitive subnational debt markets. State and local governments and their special purpose vehicles issue bonds in capital markets to raise funds for 
infrastructure and other projects for public purposes. With approximately 50,000 subnational issuers, annual issuance averages $\$ 425$ billion, with debt outstanding at about $\$ 3.8$ trillion. Notwithstanding episodical cases of defaults, the overall default rates are extremely low. ${ }^{4}$

Such a large and well-functioning market was not created overnight. The US introduced a series of institutional and legal reforms throughout its 200-year capital market history (for a review, see Liu et al. 2013a; 2017). Notable reforms include (1) state reforms of off-budget vehicles in the 1840 s to bring transparency and link debt service with revenue base; (2) the development of revenue bonds and their legal foundation in the late nineteenth century; (3) the securities laws in the 1930s; (4) Chapter 9 of the federal Bankruptcy Code for municipalities in the 1930s Great Depression; (5) the creation of the Municipal Securities Rulemaking Body in 1975; (6) continuous reforms at the state level for local governments; and (7) the creation of the nationwide Electronic Municipal Market Access. According to Liu et al. (2013a), some of the reforms were introduced to respond to subnational debt crisis (e.g., reforms of state off-budget vehicles in the 1840s and the enactment of Chapter 9 during the Great Depression), while other reforms targeted debt instruments, market institutions, and market transparency (e.g., revenue bonds, securities laws, the Municipal Securities Rulemaking Body, and Electronic Municipal Market Access).

Development of the subnational debt market has been on the policy agenda of many developing and emerging economies since the 1990s (see Liu and Webb 2011; Canuto and Liu 2013). After the subnational debt crisis in the mid- to late-1990s in several countries as noted, the development slowed down. Since the 2008 financial crisis, there has been renewed interest. As noted by Canuto and Liu (2013), SNGs in various countries have already issued bond instruments (for example, in the PRC, India, Colombia, Mexico, Poland, the Russian Federation, and South Africa). Some other countries are developing policy frameworks for preparing SNGs' access to financial markets (for example, Indonesia preparing legislations and Peru piloting capacity-building activities). As explained below, subnational credit market development in India, Indonesia, the PRC, and the Philippines present different reform challenges and experiences, yet they help delineate certain common principles underlying their reform efforts. ${ }^{5}$

\subsection{India}

In India, the state subnational debt market differs substantially from the municipal one, with the former having a long history while the latter is nascent but with a new spurt of growth. ${ }^{6}$ Article 293 of the Constitution grants to states the legal authority to issue debt but forbids their borrowing overseas. ${ }^{7}$ The debt-to-gross domestic product (GDP) ratio across all states was about 25 percent in 2019/2020, stable over the last several years. In general, market borrowing of public enterprises owned by states is backed by state guarantees with contractual budgetary provisions for debt services.

Historically, the central government borrowed and onlent to states (for example, loans from the center accounted for 50 percent of states' borrowing in 1997/1998). The Twelfth Finance Commission (FC) established in 2002 (Government of India 2004) recommended states be given more autonomy and market access, and the financial intermediary role of the central government be discontinued. ${ }^{8}$ Loans from the center gradually declined and were discontinued in 2005. Market-based borrowing by states increased over time, from 15.1 percent of total 
borrowing in 2002 when the reform began, to 51.4 percent in 2018, 54.3 percent in 2019, and projected 57.9 percent in $2020 .{ }^{9}$ Market borrowings are managed by the Reserve Bank of India through an auction platform.

As reviewed by Rangarajan and Prasad (2013), with more freedom, states also bore the greater responsibility of managing their debt. The new lending policy has led to greater market discipline and transparency to enhance credibility among the market participants. Competition gradually increased among states to avail the best market terms and obtain credit ratings. There has been evidence of some variation in the spreads among states, with some states borrowing at slightly lower rates, although the overall range of the spreads has been narrow.

Commercial banks (mostly public banks) hold the majority of state debt securities at about 50 percent, insurance companies hold about 26 percent, and other investors hold the rest. ${ }^{10}$ Commercial banks' statutory reserves requirements include state securities which are collateralized by "automatic" intercepts from the state treasury account, with no restructuring or defaults associated with these. ${ }^{11}$

In contrast to the large state securities market, the municipal securities market is smaller but shows promising momentum. It was not until 1992 that the 74th Amendment to the Constitution created the third-tier government. The first municipal bond was issued in 1997, followed by 24 more issues as of 2015 , totaling ₹17.47 billion ( $\$ 389$ million). The market grew more rapidly after the 2015 regulation by the Securities and Exchange Board of India (SEBI), which stipulates that the municipal bonds in capital market public offering be revenue bonds. From June 2017 to January 2019, seven municipal bonds were issued totaling ₹41.09 billion ( $\$ 601.5$ million). ${ }^{12}$ Still, only a limited number of urban local bodies (ULBs) in India have investment grade ratings. The cost of borrowing would be prohibitively high for ULBs with below investment grade ratings. ${ }^{13}$

\section{$2.2 \quad$ Indonesia}

Still at an early stage of development, the Indonesia bond market (sovereign, corporate) is relatively small, with total bonds outstanding at less than 20 percent of GDP. Sovereign bonds dominate, with corporate bonds accounting for only 3 percent of GDP. ${ }^{14}$ The domestic corporate bond market remains limited, with a few repeat issuers dominating the corporate debt offerings. As a result, Indonesia has one of the smallest corporate bond markets in Asia. ${ }^{15}$

The history of Indonesia's decentralization is shorter (started in 2001) than that of some other countries. ${ }^{16}$ It takes time to establish intergovernmental systems. Although SNGs in Indonesia have not yet issued bonds, the government has been active in developing a regulatory framework for SNG borrowing and bond issuance (see next section). As an intermediary step, SNGs have access to the Indonesia Infrastructure Development Fund for loans to finance infrastructure while the fund has direct access to the market. It would also be feasible for SNGs with strong revenue bases and a history of sound financial management to pilot the issuance of bonds.

There are encouraging developments in the domestic bond market, which over time should bode well for the development of the subnational credit market. First, both the sovereign and corporate markets have continued to grow, after a short interruption during the global financial crisis. The share of sovereign and corporate bonds to GDP increased from 15 percent in 2015 
to 19 percent in 2019, with the corporate bonds' share of GDP increased from 2.3 percent in 2016 to 3 percent in $2018 .{ }^{17}$

Second, all major types of institutional investors (financial institutions, insurance companies, pension funds and mutual funds) have invested in government and corporate bonds; particularly worth noting is that 17-18 percent of corporate bonds are held by pension, insurance, and mutual funds, which have asset-liability matches that are better suited for subnational bonds (World Bank 2016a).

Third, for corporate bonds, pricing is more responsive to credit risks. The higher-rated issuance carries a lower cost of spread; for example, for investment grade bonds, AAA-rated bonds have a medium coupon rate of 9.6 percent compared with BBB-rated bonds which have a higher medium coupon rate of 12 percent (World Bank 2016a).

In the medium to long term, the subnational debt market will need to address several challenges. First, cost of financing is high even for corporate bonds with a high rating. The medium coupon rates for highly rated corporate bonds (AAA and AA) range from 9.6 percent to 10.1 percent, with 350 basis points for a larger range of coupon rates (World Bank 2016a). Second, a high degree of bond market volatility as suggested by wide ranges of coupon rates can be punitive for new market entrants such as SNGs with a new asset class. Although bank loan rates have a slightly lower interest rate than bonds, the short maturities imply volatility and a potentially higher cost of refinancing (World Bank 2016a).${ }^{18}$ Finally, strengthening regulatory frameworks for subnational borrowing will go a long way to help develop the subnational credit market.

\subsection{People's Republic of China}

The subnational debt market development in the PRC has gone through three distinct phases. The following review of the first two phases draws from Liu and Qiao (2013a) and Liu (2011). ${ }^{19}$ During the first phase, from the early 1990 s to 2009 , SNGs relied on a combination of sources to finance infrastructure: central government onlending, SNGs' financing vehicles, borrowing directly from the financial markets (mostly loans but also bonds), and subnational land-asset-based finance. These financing instruments spurred rapid infrastructure development, but their limitations became evident over time. With central government onlending, SNGs have no market interaction with creditors, and the borrowing power is disconnected from payment obligations. The SNGs' off-budget financing and debt are nontransparent. Financing infrastructure through land lease is not sustainable in the long run, because of the up-front collection of leasing fees.

The second phase, from 2009 to 2014 , focused on preparations for the transition to a modern regulatory framework. Capacity building was an important part of design because critical preconditions for the issuance of bonds directly by provinces did not yet exist. The SNGs had no market access experience, and it would take time to develop credit rating systems. The SNGs would also need to set up institutions such as debt management offices to integrate debt management into overall budget preparations. During this transition phase, provinces were permitted by the central government to issue bonds, with the central government acting as the issuing agency, so that provinces could learn the auction process of debt issuances. From 2009 to 2011, CNY600 billion (\$90 billion equivalent) of provincial bonds was authorized and issued. In 2011, the State Council approved piloting of direct bond issuance of CNY23 
billion ( $\$ 3.56$ billion equivalent) by four cities, without the central government acting as the issuing agency.

The ongoing third phase started with the new Budget Law (August 2014) and the State Council's directives (September 2014) outlining a modern framework for subnational debt management. Provinces are permitted to borrow on budget, but their capacity to incur debt is subject to regulatory limits, approval of the People's Congress, and assessment of the provinces' market creditworthiness.

To implement the new law, an important operation was launched to swap the existing debt of SNGs' financing vehicles into SNG bonds within a three-year timetable, with the aim to bring off-budget debt on budget for transparency, improve SNG debt profile by converting shorter maturity debt into longer maturity bonds with lower cost, and facilitate the development of the subnational securities market. The issuance of new bonds was capped to control aggregate indebtedness. Under the new law, SNGs are required to disclose key financial data such as revenue, expenditures, and debt.

From 2015 to August 2018, the amount of debt stock swapped totaled CNY12.19 trillion ( $\$ 1.76$ trillion). The nature of the existing debt stock changed from loans or corporate bonds issued by subnational government financing vehicles to bonds issued by SNGs. As of October 2019, subnational bonds accounted for 99 percent of all SNG debt. SNG bonds, issued in the interbank market and stock exchanges, have now become an active part of the fixed-income securities market in the PRC. By the end of October 2019, SNG debt outstanding was CNY21.38 trillion (\$3 trillion), accounting for 21 percent of GDP. ${ }^{20}$

Several notable trends have emerged. Yield spread of publicly auctioned debt has differentiated among provinces, and the spread is higher for longer maturity than for shorter maturity, as pricing is more responsive to differentials in credit risks. Maturities of bonds have extended and differentiated into five categories, from three years to 30 years. Revenue bonds, an important bond instrument for infrastructure financing when debt is serviced by the revenue generated by the project being financed, have grown. The investor base is diversifying - although commercial banks continue to be the main holders of SNG bonds, their share has declined. Institutional investors have increased their purchase of SNG bonds. Foreign institutional investors have also purchased SNG bonds. Finally, SNGs can directly coordinate with the market on their own to decide the timing of issuance and maturities of bonds, without needing guidance from the central government. The central government continues to provide guiding principles such as the maturity of the bond to match the project cycle.

\subsection{Philippines}

In the Philippines, the Local Government Code of 1991 commenced decentralization and defined the structure of local government units (LGUs) in a unitary system (the discussions on the Philippines prior to 2013 draw from Liu et al. (2013b) unless otherwise indicated). The code assigned greater spending responsibilities to LGUs, entitling them to receive more fiscal transfers and expanding their own revenue power. Nonetheless, aggregate LGU spending as a share of national government spending has remained low, averaging 18.2 percent from 2009 to 2016, with a declining trend during the period (Diokno-Sicat and Maddawin 2018).

The LGUs, as a whole, run a budget surplus, and their borrowing is low (with debt outstanding about 1 percent or less of GDP). ${ }^{21}$ The low level of indebtedness is partly explained by the 
limited infrastructure responsibility assigned to LGUs. The national government control and fund major infrastructure projects and its agencies continue to play major roles in the delivery and finance of local services.

The LGU debt portfolio reflects the Philippines' largely bank-denominated credit system. Bank loans account for almost 99 percent of LGU debt outstanding, and the share of bonds in LGU debt outstanding has declined from just a bit over 1 percent in 2013 to about 0.26 percent as of June $2019 .{ }^{22}$ Bonds are purchased mostly by private banks and guaranteed by the LGU Guarantee Corporation (LGUGC) and the private Philippine Veterans Bank that can accept LGU deposits (private financial institutions are generally not allowed to serve as depository banks for LGUs). The maturities of loans average about two to four years and of bonds about seven years.

The 1991 decentralization policy recognized the importance of private financing to help LGUs attain self-reliance and become effective partners in the attainment of national goals. ${ }^{23}$ Using its guarantees, the LGUGC spurred private financial institutions' direct lending to LGUs, water districts and electric cooperatives. The fixed-income exchange has developed a "yield curve" for government securities that can be used as a benchmark for other fixed-income obligations including LGU bonds. The Philippine Water Revolving Fund, established in 2008 to mobilize private funds to the water sector, qualified several private financial institutions to participate. $^{24}$

However, progress in private financing of LGUs has been slow. ${ }^{25}$ Loans from government financial institutions (GFIs) dominate the LGUs' outstanding debt, with loans outstanding from private banks accounting for a declining share, from about 13 percent in 2010 to 9.81 percent in June 2019. ${ }^{26}$ LGUs must use GFIs for depositing fiscal transfers. GFIs can intercept or offset deposits to secure loan repayments, thus lowering the risk premium. GFI loans directly compete with the loans and bond market of private financial institutions. With no LGU bond issues to guarantee, the LGUGC, in which private financial institutions had invested, closed at the end of 2019. In the long term, the development of a competitive subnational credit market in the country would benefit from greater infrastructure spending responsibilities by LGUs and competition among financial institutions.

\section{REGULATORY FRAMEWORKS FOR SUBNATIONAL DEBT MARKET}

As argued by Liu and Webb (2011), the design of regulatory frameworks for subnational debt markets must overcome a unique challenge: the so-called common pool and free riders. The interests of an individual SNG may diverge from the common national interest. When a subnational government follows unsustainable fiscal policy, it may only bear part of the cost of its misbehavior, but would still receive all of the accrued benefit, if (most of) the other SNGs continue to follow good fiscal behavior. Subnational borrowers "have an incentive not to repay their lenders as principals because they perceive that they will be bailed-out by the central government in case of default, resulting in moral hazard" (Liu and Webb 2011, p. 14).

Thus, unconditional bailouts create a moral hazard. "Market participants may tolerate unsustainable subnational fiscal policy if past history backs their perception that the central government implicitly guarantees the debt service of the subnational government" (Ianchovichina et al. 2007, p. 114). However, regulatory frameworks alone cannot ensure 
sustainable fiscal policy. A fiscal transfer system simply fills the financing gap of SNGs, which would incentivize them to run a larger fiscal deficit.

This section summarizes regulatory reforms in India, Indonesia, the PRC, and the Philippines, and highlights important design issues.

\subsection{India}

The regulation of subnational debt in India, which is anchored by its federal system, has gradually moved toward a rule-based framework and market discipline. As discussed by Rangarajan and Prasad (2013), under the old system, the states' borrowing was limited by the central government's annual discussions with states on their financing plans, leveraged by the central government's loans to the states. Although it limited explosive debt growth and systemic insolvency, the system did not prevent states from fiscal deterioration in the late 1990s. Fiscal deficit, debt, and contingent liabilities grew rapidly because of rising expenditures on salaries, retirement benefits, pensions, and subsidies to state-owned enterprises; and states increasingly used new borrowings to finance operating deficit.

To address the fiscal decline, fiscal consolidation included the standard measures of expenditure and taxation reforms (Ianchovichina et al. 2007). But, importantly, as reviewed by Rangarajan and Prasad (2013), a rule-based framework was developed, which included a fiscal responsibility law to ensure fiscal/debt sustainability. The framework underpinned the move to market-based borrowing for states. However, large interest payments on high-cost legacy loans from the center hindered fiscal adjustment. Cognizant of moral hazard in debt relief, per the recommendations of the Twelfth FC (established in 2002) and the Thirteenth FC (established in 2007), the center restructured or wrote off its loans, conditioned on the state's reform commitment and progress (e.g., enacting a fiscal responsibility law and establishing milestones for attaining fiscal and debt targets).

The key provisions of fiscal responsibility laws are similar across states with respect to debt and deficit: borrowing not to finance operating deficits; limits on deficit, debt and guarantees; and fiscal transparency. Some states also included a guarantee redemption fund for servicing any contingent liabilities and a provision of no guarantee for private entities.

All states have adopted a municipal law, which, among others, authorizes municipal governments to issue debt and create a sinking fund for debt service. In 2019, SEBI amended its 2015 regulation for municipal securities, similar in many ways to that for corporate securities. ${ }^{27}$ The regulation covers the entire process of municipal bond issuance, trading, refinancing and reporting. It requires a municipal issuer to, inter alia, submit and disclose three-year audited financial statements including details of all liabilities, establish an escrow account dedicated to debt service, have surplus income for the prior three years, have no defaults for at least a year, undertake credit ratings, and disclose all information of material nature.

\subsection{Indonesia}

The regulatory framework for subnational borrowing in Indonesia is established by Law 23 of 2014, which sets forth the key provisions. The Ministry of Finance Decree 180-PMK-07-2015 provides implementation details. The Financial Services Authority (OJK), the Indonesian 
financial market regulator, has provided guidelines regarding the issuance of regional government bonds from the perspective of the financial market. ${ }^{28}$

The framework has several key elements. First, the regional council is the approval authority for bond issuance. Second, the framework defines the purpose of the subnational bonds: to finance public investments and infrastructure. Third, it requires that annual budgets include provision for scheduled debt service, which is a major step forward, considering the legacy of debt arrears by many SNGs. Fourth, general allocation grants or the revenue-sharing fund to an SNG can be intercepted if the SNG has arrears to the central government or the PT SMI, with the intercept linking to factors such as subnational fiscal capacity. ${ }^{29}$ Fifth, SNGs need to strengthen fiscal transparency by compiling and reporting financial data (such as debt outstanding, budget deficit, debt service ratio). Finally, SNGs need to strengthen debt management capacity for monitoring risks.

Since 2014, ongoing reforms have continued to refine regulatory frameworks and harmonize provisions from different agencies, for example, Ministry of Finance, OJK, and the Indonesia Stock Exchange (IDX), as anticipated by Law 23/2014. One such reform relates to defining the sources of revenue for different types of subnational bonds. A provision in Government Regulation 30/2011 states that debt service payments for regional borrowing should be taken from project revenues, while Law 23/2014 allows a local government to create a reserve fund for debt service, implying that the general budget can be used to finance public investments that do not generate sufficient revenues. Another regulation relates to the purpose of the debt. Government Regulation 30/2011 requires bonds to be used for financing revenue-producing infrastructure projects, while Law 23/2014 recognizes that a regional loan might be used to finance a budgetary deficit, which again seems to recognize that some public investments may not generate sufficient revenues to cover debt service.

In 2018, Regulation No. 56 in 2018 set forth provisions on subnational borrowing, which put a regulatory limit on outstanding debt in relation to an SNG's fiscal capacity. The Omnibus Law on Job Creation in 2020 amends Law 23 of 2014, with two relevant aspects: (1) approval from the regional council on borrowing is no longer required, though the consideration and approval from the central government remain; and (2) SNGs may issue bonds and/or sukuk to finance public infrastructure and investments. ${ }^{30}$

\subsection{People's Republic of China}

The new budget law and the State Council's directives in 2014 set the framework for regulating the PRC's subnational debt market. ${ }^{31}$ The new law specifies that SNGs are allowed to borrow by issuing bonds within the approved debt limit, and any other channels of borrowing are prohibited. SNGs are not permitted to provide guarantees for debts of any entities or individuals, subject to any limitations otherwise provided by law. The new legal framework also contains provisions for the issuer, the debt instruments, the issuing procedures, the purpose of borrowing, and the responsibilities of SNG borrowers.

SNGs can only borrow within a statutory ceiling of outstanding debt. The State Council submits to the National People's Congress the annual aggregate borrowing limit for government, including both the central government and SNGs. Within the aggregate annual limit, the State Council sets debt limits for each individual province. An SNG at each level must incor- 
porate debt into its annual budget and submit it for approval and supervision by the People's Congress at each level.

SNG bonds are issued to finance infrastructure and social services. Two major types of bond instruments and their respective revenue sources for debt service are specified: general bonds are collateralized by the broad revenue base of the issuer (province), and special bonds (e.g., project bonds, which are similar to revenue bonds) are collateralized with the revenues generated by the project being financed.

The government has issued the Emergency Response Plan for Subnational Government Debt and the Guidance on the Classification and Treatment of Risks in Subnational Government Debt. The Ministry of Finance has established an early warning system and conducts periodic assessments of debt risks for SNGs at all levels-provinces, municipalities or prefectures, and counties/districts. The assessments cover key indicators such as debt ratio, debt servicing ratio, interest expense, and maturity. All provinces are required to develop risk resolution and emergency response plans.

\subsection{Philippines}

In the Philippines, the Local Government Code of 1991 grants LGUs the general power to borrow, but also with restrictions (Liu et al. 2013b). ${ }^{32}$ Together with the provisions put forward by financial sector regulators, the regulatory framework for LGU borrowing is rigorous: (1) there are numerical limits on the ratio of debt service to LGU revenue; (2) borrowing must finance long-term investments; (3) LGUs cannot incur operating deficits and must appropriate in their annual budget amounts sufficient to cover debt obligations; and (4) the fiscal transfers can be used by lenders as intercept for loan repayments.

In addition, as noted by Liu et al. (2013b), the New Central Bank Act (Republic Act 7653) requires that, as a condition of borrowing, the monetary board render an opinion on the impact of the borrowing on monetary aggregates, the price level, and the balance of payments. For a sovereign guarantee, there is a more rigorous test, and approval is required from the secretary of finance. No subnational government has borrowed with such a guarantee, nor has any borrowed in foreign currency.

An agreement signed among government agencies in 2002 requires that GFIs, the central bank, and the LGUGC submit data on LGU debt to the Bureau of Local Government Finance (BLGF) under the Department of Budget and Management. LGUs are also required to submit quarterly financial statements to BLGF. The central bank monitors GFI loans to LGUs and the purchases of LGU bonds. BLGF works closely with the Municipal Development Fund Office in tracking LGU borrowing and debt service capacity.

The rigorous monitoring and supervision have helped prevent systemic defaults. BLGF provides detailed monthly data on net debt service ceiling and borrowing capacity for each LGU, as well as detailed data from financial institutions on LGU indebtedness. The aggregate debt service payments of LGUs are equal to only 2 percent to 3 percent of what is defined as revenue capacity of LGUs. ${ }^{33}$ 


\section{SOME KEY REFORM ISSUES}

The above country experiences provide valuable lessons for other countries that wish to grant or expand subnational borrowing power. Summarized below are some key thematic reform issues, which would also be relevant to the continuing reform efforts of countries discussed in this chapter. The regulation for subnational borrowing is intertwined with the intergovernmental fiscal system. Moreover, ex-ante regulation would need to be enforced through effective debt restructuring. Finally, contingent liabilities and risks may not be easily captured by existing accounting systems, making it difficult to regulate these liabilities. While it is beyond the scope of this chapter to examine these issues in depth and empirically, this section highlights relevant key issues for policymakers to consider in ensuring the sustainability of subnational borrowing.

\subsection{Intergovernmental Fiscal System}

Three aspects of intergovernmental fiscal systems have immediate bearing on subnational borrowing: (1) what are the expenditure responsibilities, particularly in the area of public infrastructure investments, for SNGs?; (2) do SNGs have reliable revenue sources to service debt?; and (3) is there sufficient fiscal and debt space for the subsovereign? These questions are examined below. ${ }^{34}$

The question of whether SNGs have responsibility for infrastructure investment is an essential part of designing the intergovernmental fiscal system, that is, expenditure assignment. The golden rule - borrowing is to finance public investments not operating deficit - is a core element of regulatory frameworks for subnational borrowing in all the country cases. This issue can become front and center at the time of macroeconomic crisis when SNGs may desire, and push for, borrowing power to ease liquidity as they are starved for cash while central government transfers are squeezed.

The second question on revenues collateralizing debt service is based on a simple fact: all debts must be repaid. Thus, the sources of SNG revenues and their reliability and predictability for debt service are important to investors (if there is no expectation of bailouts). The more clarity there is on the sources, the easier it is for investors to price default risks (and reward fiscally responsible SNGs by providing a lower cost of financing).

There are three sources of SNG revenues: own-tax revenues, fees (such as cost recovery fees on public services), and fiscal transfers from the central government. Own-tax revenues and fiscal transfers are the main sources of collateral for general obligation bonds, and cost recovery fee charges (e.g., for water and sanitation, electricity, airports) are the main sources of collateral for revenue bonds.

There are profound intergovernmental fiscal reform issues concerning each of the three subnational revenue sources. Regardless of whether SNGs collect their own-source revenues or rely on central government transfers, the reform covers a broad range of issues concerning personal income tax, corporate income tax, value-added tax, sales tax, property tax, equalization transfers, or conditional grant transfers. Moreover, the design issues concerning user fees differ substantially across infrastructure subsectors, with some sectors achieving cost recovery more easily (such as energy and airport) than other sectors (such as water and sanitation). 
Adding to the complexity is the existence of a variety of revenue systems within a country. In a federal system such as India, each state decides the modalities of the revenue system for its local governments. Even in a unitary system such as the PRC, each province sets out the revenue-sharing system for its cities, districts, and townships, within the broad revenue framework established by the central government.

SNGs in many countries rely heavily on central government transfers, but the design of transfers confronts the trade-off between equity and efficiency, as well as the basic question of the appropriate division of responsibility and financing sources. Cost recovery for public services in infrastructure (such as water and sanitation) is low even in many middle-income countries.

This does not mean that SNGs cannot have borrowing power until the reforms in each of these areas are completed. It does mean, however, that granting and/or expanding SNG borrowing power must be cognizant of the revenue issues, and the reform of intergovernmental fiscal systems is intertwined with the regulatory frameworks for SNG borrowing. For example, fiscal transfers will need to be reformed to become steady and predictable, not influenced by political negotiations between the central and subnational governments. Revenue bonds can be piloted for those public infrastructure projects with good cost recovery history.

It goes without saying that any clarity on collateral would require reforms in subnational financial management, so as to provide uniform benchmarking standards in collecting, reporting, auditing, disclosing, and monitoring fiscal data.

The third question - on the division of debt space between the central government and SNGs - is an important one:

For any given resources available to repay the total public debt, the borrowing space is ultimately split between national and subnational entities. This split should ideally reflect the relative position of both levels of government in terms of taxation capacity, revenue sharing and expenditure responsibility, particularly concerning infrastructure investments, as well as the institutional arrangements for sharing resources (Liu and Pradelli 2012, p. 7).

In the PRC, the low share of sovereign debt to GDP (below 20 percent) over the decades affords more debt space to SNGs, which takes up a major share of public investments.

Research has shown that total public debt thresholds in the range of 80-90 percent of GDP would draw the line between growth-enhancing effects of government debt and growth-hampering ones. ${ }^{35}$ The European Union Maastricht Treaty establishes indicative numerical thresholds for member states, that is, public debt as 60 percent of GDP and fiscal deficit as 3 percent of GDP.

The issue of debt space becomes more relevant during a macroeconomic crisis when national governments in many countries launch countercyclical fiscal and monetary measures, and sovereign debt rapidly increases (such as during the 2008 global financial crisis and the ongoing COVID-19). A country that is thinking of granting or expanding subnational borrowing power must recognize that expanding subnational borrowing should not be viewed as a way of bridging expenditure-revenue gaps or easing liquidity constraint. Rather, a long-term view is required as to the allocation of financial resources (i.e., credit supplies from the financial system to finance public borrowing) between sovereign and subsovereign. Moreover, SNG debt dynamics become an important part of public debt dynamics when subnational debt grows. 


\subsection{Debt Restructuring}

From the financial market perspective, creditors are keenly interested in the type of insolvency system or legal remedies available for dealing with defaulting subnational borrowers. Establishing a predictable set of insolvency rules is essential to capital market development. While the financial implications of default cannot be fully spelled out ex ante, insolvency procedures guide restructuring and negotiations. Lenders are aware of the circumstances under which they may have to take losses. This helps achieve better pricing of credit risks and enhances predictability on returns to capital.

The lack of insolvency procedures is less of a concern when higher levels of government exercise tight control over subnational borrowing, or when only a few lenders (such as public banks) provide credit to SNGs. Insolvency procedures become more important as the subnational bond market develops. A large number of bondholders exacerbate the collective action problem with protracted and costly negotiations between a debtor and numerous creditors.

Moral hazard is at the heart of debt restructuring challenges. As noted in the previous section, the federal restructuring of the states' legacy debt in India aimed to avoid moral hazards while helping reduce the high cost of legacy debt and helping states comply with newly established fiscal rules. The restructuring of the rural school legacy debt in 2007 in the PRC also established rule-based write-offs to avoid moral hazard (Liu and Qiao 2013b).

International experience shows that developing an insolvency system is more challenging than developing ex-ante fiscal/debt rules. ${ }^{36}$ Debt restructuring must not only be cognizant of moral hazards, but must also involve the respective role of each tier of government in addressing the politically challenging tasks of reducing spending and increasing revenues. Debt restructuring itself is already daunting, as it needs to protect creditors' rights while protecting essential public services (public assets cannot be liquidated and government cannot be dissolved, as in private bankruptcy). When the US enacted Chapter 9 of the Bankruptcy Code for municipalities, the country's intergovernmental system was already well defined; still it took four years for Congress to deliberate on and enact Chapter 9. In many countries, including the country cases discussed in this chapter, the intergovernmental fiscal system is still evolving, reforms are multifaceted, and institutional capacity is still developing.

\subsection{Managing Implicit/Contingent Liabilities and Fiscal Risks}

Several types of liabilities may not be easily captured or quantified, thus making them more difficult to regulate. Yet these liabilities have a significant impact on subnational fiscal and debt sustainability.

\section{Deficit financing through arrears}

SNGs may delay wage and pension payments or payments to suppliers when facing economic or fiscal stress. In India, the accumulation of such arrears was an integral part of the state fiscal crisis in the late 1990s. Fiscal accounting, being on the mandated cash system, did not capture the depth of fiscal deterioration, owing to non-reporting of accrued liabilities. Addressing the arrears was a core part of state fiscal reforms in the early $2000 \mathrm{~s}^{37}$ 
Liabilities from special purpose vehicles (SPVs) and public-private partnerships (PPPs) SNGs create SPVs to undertake public investments. In the US, SPV revenue bonds account for about two-thirds of $\$ 400$ billion annual issuance of subnational bonds. ${ }^{38}$ In France, sociétés d'économie mixte locales (SEMs) (i.e., a PPP) deliver infrastructure such as water and sanitation across a large number of small municipalities. ${ }^{39}$ SEMs' net debt outstanding is often close to that issued directly by SNGs. ${ }^{40}$

In the US, revenue bonds are outside the state debt limit, as debt service comes from project revenues, not state budgets. But the regulation of revenue bonds is extremely rigorous, covering issuance process, independent trusts that hold bond proceeds and debt service escrows, credit ratings, audits, accounting, high standard of market disclosure, and legal enforcement. PPP risks are also disclosed in annual audited public financial statements, and are subject to scrutiny of independent credit rating agencies.

SNGs have utilized SPVs for infrastructure projects in many countries, and PPPs experienced a sevenfold increase in developing countries during 2006-2008 compared with 1990-1992 (Engel et al. 2009). Both instruments have implications for subnational balance sheets, as SNGs may provide guarantees to SPVs or commit to PPP contractual obligations (such as subsidies or revenue support).

It is important to develop regulatory frameworks to define, measure, quantify, disclose, and monitor these liabilities and fiscal commitments, and assess their risks to budgets. Compounding this difficult task are the wide varieties of legal contractual relationships in PPPs. The essence of a legal contractual agreement for a PPP project is to spell out risk-sharing arrangements between a government and a private operator, including the fiscal commitment of the government to the PPP project. The legal contracts are to help mitigate a variety of risks in PPPs, such as revenue shortfalls, and macroeconomic, regulatory and operational risks. The contractual agreements differ in substance and form across PPP sectors and projects. The types of macroeconomic risks (such as currency volatility) and regulatory risks (such as tariff setting for cost recovery) differ across countries.

\section{Land-asset-based financing of infrastructure}

SNGs in developed and developing countries have used these instruments (e.g., land sales, lease auctions) to generate revenue from publicly owned land assets. Land is often the most important public contribution to PPPs in metro (subway) lines, airports, or other large infrastructure projects (Peterson and Kaganova 2010). ${ }^{41}$

There are fiscal risks. During economic downturns and budget shortfalls, the government could be under pressure to use land-asset revenues to finance the operating budget, which can be made easier when sales are conducted off-budget. Bank loans for financing infrastructure are often backed by land collateral and the expected appreciation of future land value. The volatility of land and real estate markets can create sizable nonperforming loans.

It is critical to develop prudential rules, which could be guided by the following principles: (1) asset sale proceeds are ring-fenced for capital spending, not for the operating budget; (2) collateral/loan ratios are linked to banking regulations; (3) land financing is linked with medium-term capital budgeting; and (4) data on public land inventories, valuations, sales, and contributions to PPPs are reflected in SNG financial statements. 


\section{Pension and health-care liabilities}

As SNGs take on more expenditure obligations, other liabilities could strain SNG debt sustainability. Meeting pension and health-care obligations is a serious long-term challenge in advanced economies, including at the state level in federal countries. ${ }^{42}$ These obligations could also grow for SNGs in large middle-income countries.

\section{Structured financial products}

During times of macroeconomic stress and reduced fiscal space, some SNGs may be tempted to use instruments such as swaps and other derivative instruments. But these instruments often restructure the profile of the debt such as interest rate and maturity in a way that may lower the cost of financing in the short term, but could increase longer-term risks of volatility and higher financing cost. Public accounting standards will need to keep pace with developments in these new products, and in evaluating their costs and risks.

\section{Foreign exchange risks}

If SNGs are permitted to borrow in foreign currency, the cost of debt service can become unsustainable when local currency depreciates during a macroeconomic crisis. For example, foreign currency debt dominated local government borrowings during 2007-2013 in Hungary, reaching over 60 percent of local government debt. The Hungarian forint depreciated against the Swiss franc, the euro, and the US dollar in the aftermath of the 2008 global financial crisis. The costs of servicing and refinancing the debt increased significantly despite the benefits of the debt's low interest rate (Liu and Peteri 2015).

In India and the PRC, SNGs are not authorized to borrow in foreign currency. When local enterprises in the PRC borrow from abroad, the regulation stipulates that SNGs should not provide any guarantees or any form of credit support. When the national government borrows from international financial institutions (such as multilateral and regional development banks) and onlends the proceeds to SNGs, the foreign exchange risks are borne by the SNGs in both countries.

\section{MACROECONOMIC FUNDAMENTALS}

The sovereign's macroeconomic fundamentals are key to the fiscal sustainability of SNGs and thus to their capacity for sustainably raising funds from financial markets. As reviewed by Liu and Tan (2009), major international rating agencies, such as Fitch, Moody's, and S\&P, cap subsovereign credit ratings by the sovereign credit ratings; rarely do subsovereign ratings exceed that of the sovereign.

According to Liu and Tan (2009), a country's macroeconomic management and countrywide risks affect the broader economic, fiscal, and financial conditions under which an SNG operates and also restrict an SNG's ability to raise funds. With its wide range of constitutional powers giving it first claim over the country's foreign reserves and other resources, the national government in a financial crisis is thus likely to fulfill its external or domestic debt obligations ahead of the SNG. The rating "ceiling" relationship applies less strongly to domestic currency debt instruments. Even in cases where the SNG possesses foreign currency reserves that are out of the national government's reach, the national government nevertheless could impose nationwide capital or exchange controls to restrict capital outflows and thereby 
disallow the SNG from repaying its foreign debts. In short, the sovereign is unlikely to default before any SNG does.

As noted by the Moody's Investors Service (2018),

In assessing the systemic risk score, we use the country's sovereign bond rating. Generally, an [regional and local governments] RLG is unlikely to be rated above the sovereign's rating, which means that the sovereign bond rating represents an effective cap on the RLG's rating. There may be certain instances, however, when an RLG's rating can exceed the sovereign's rating. In these cases, the systemic risk score may be one or two notches above the sovereign rating. Given the significant macroeconomic and financial linkages between the sovereign government and lower-tier governments, however, it is unusual for an RLG to be rated more than two notches above the sovereign's rating.

The COVID-19 crisis has shocked global economy, trade, investment, and supply chains. Its impact on subsovereign finance and debt sustainability is still unfolding, and it will take time to make a comprehensive assessment, which is beyond the scope of this chapter. But a review of the impact of the 2008 global financial crisis on subnational borrowing is illustrative.

The 2008 global financial crisis had a profound impact on subnational finance across countries (Canuto and Liu 2010). Slower or negative national and regional economic growth generally reduced the SNGs' own revenues, while their expenditure obligations remained more rigid, resulting in wider financing gaps.

A liquidity squeeze and lower risk appetite led to higher financing costs. Yield spread for subnational bond issuance steadily increased from the first quarter of 2008 to the second quarter of 2009, whereas maturity exhibited a generally declining trend. The higher financing cost of bond instruments underestimated SNG borrowing costs, as only the most creditworthy SNGs had access to capital markets.

Central governments launched a range of measures to help SNGs weather the crisis such as (1) relaxing fiscal and indebtedness targets and broadening the fiscal space for new borrowing; (2) creating a credit line for SNGs that suffered a loss of fiscal transfers; (3) providing low-cost loans for SNGs and increasing fiscal transfers; (4) helping provide financing for SNG infrastructure spending and other core services; and (5) expanding SNG access to capital markets through subsovereign bond issuance (see Canuto and Liu 2010 for a summary of these measures in select countries).

The challenges facing SNGs with respect to borrowing in the aftermath of COVID-19 are not substantively different from any other macroeconomic shocks: rigidity of spending particularly of a recurrent nature, declining revenues, increasing financing gaps, liquidity constraint, and higher financing cost. Countercyclical fiscal and monetary policies are at the purview of the central government. Whether and to what extent the central government can help alleviate the financing pressure on SNGs will depend on a specific country's conditions and to a larger extent its aggregate fiscal space and the resilience of its economy. What is important to consider is that in response to the fallout from COVID-19, countries launched countercyclical fiscal and monetary measures, and sovereign debt has rapidly increased. A long-term view is required as to the allocation of financial resources (i.e., credit supplies from the financial system to finance public borrowing) between sovereign and subsovereign.

Although COVID-19 may delay the pace of regulatory reforms and subnational debt market development, the direction of the reform remains the same, and will need to address the set of issues discussed in previous sections. 


\section{CONCLUSIONS}

A key lesson that can be drawn from the experience of the four countries is that reform is gradual and path dependent. The transition from central government onlending or public bank lending to market-based financing takes time and requires carefully sequenced reforms. In India and the $\mathrm{PRC}$, each phase of the reform process tried to resolve key bottlenecks before moving to the next phase. Despite the gradual steps taken, the synergy resulting from the many institutional and regulatory reforms had a greater impact. The experience of Indonesia shows that developing subnational credit markets is linked to the development of the sovereign and corporate securities markets. The experience of the Philippines demonstrates the challenges of introducing private competition in the subnational credit market.

Moving toward a market-based financing system is a common thread across India and the PRC, albeit at differing paces with different challenges. Thus, granting and expanding subnational borrowing power is anchored on the desire to move toward a competitive and diversified market for financing subnational infrastructure investments. A competitive capital market for subnational infrastructure financing would help lower the cost of financing and ensure a sustainable supply of credit.

Policymakers are keenly aware of the moral hazard and common pool challenges in the context of subnational borrowing and that borrowing should not be used to finance operating deficits. The issue is not just that borrowers lobby for central government bailouts, it is also a concern for creditors, as deficit financing is a joint decision of borrowers and creditors (Liu and Webb 2011). Debt restructuring guided by clear and predictable rules reduces ad hoc negotiations and increases the pain of circumventing ex ante rules (Liu and Waibel 2008b). It also guides the expectations of lenders as they enforce fiscal discipline from the market side by pricing credit risks, thus more effectively intermediating savings and investments. Addressing the significant challenge of developing an insolvency system will require a sustained effort over the medium to long term.

Subnational borrowing is intertwined with the intergovernmental fiscal system, which prescribes division among tiers of government with respect to spending, revenues, and deficit financing. If and when the central government decentralizes some or more of the infrastructure responsibilities to SNGs, two issues become paramount. First, on the source of revenue for SNG debt service, it is important to define and quantify the dedicated revenues for debt services, which not only strengthens budgetary discipline but also facilitates a close link between creditworthiness and risk premiums (Liu et al. 2013a). The second issue concerns how much fiscal and debt space there is for SNG borrowing (Liu and Pradelli 2012). This issue is particularly pertinent in times of macroeconomic stress.

Finally, financial transparency is key to sustainable subnational debt finance, as markets need to digest comprehensive information to price risks appropriately. The country cases discussed here show great attention by policymakers to the issue of financial reporting, monitoring and supervision. A long-term task is to strengthen the accounting and monitoring of complex liabilities. 


\section{NOTES}

1. The views expressed therein are those of the authors and do not necessarily reflect the views and policies of ADB, its Board of Governors or the governments they represent.

2. The term subnational refers to all tiers of government (including states/provinces, municipalities, districts, and special purpose vehicles or investment companies created by SNGs) below the central government (Liu and Waibel 2008a).

3. In this chapter, the terms subnational debt market, subnational bond market, and subnational securities market are used interchangeably. Subnational credit market mainly comprises loans and bonds.

4. Despite some well-known cases of defaults, such as Detroit in 2013 and Puerto Rico in 2017, the overall default rates for SNGs are much lower than those of the corporate sector in the US (Liu et al. 2013a; Liu and Tan 2009).

5. The review will focus on the period before COVID-19, as the chapter focuses on basic issues relating to the design of regulatory frameworks. The countercyclical policies dealing with the fallout from COVID-19 are beyond the scope of this chapter.

6. Unless otherwise indicated, the discussions on India's state debt market and regulations draw from data/analysis from the Reserve Bank of India, Rangarajan and Prasad (2013), Ianchovichina et al. (2007), and Ianchovichina and Liu (2008).

7. Indian Laws Info. Article 293 in The Constitution of India. See https://www.indianlawsinfo.com/ home/section/3722/article-293-in-the-constitution-of-india/borrowing-by-states.

8. The FC is a constitutional body appointed every five years to review and define financial relations between the center and states. There have been 15 FCs since 1951.

9. Data source: Reserve Bank of India. https://www.rbi.org.in/.

10. Reserve Bank of India. Other investors include provident funds and primary dealers.

11. Rangarajan and Prasad (2013).

12. Data calculated by author based on raw data from internet including Vinod Kothari Consultants P. Ltd. (2019). From 2017 to 2019, only one issue was backed by state guarantee (₹ 1.75 billion, \$25 million equivalent). For SEBI regulations see SEBI (Issue and Listing of Debt Securities by Municipalities) Regulations, 2015 [Last amended on 15 February 2017]. Accessed at: https://www .sebi.gov.in/legal/regulations/jul-2015/sebi-issue-and-listing-of-debt-securities-by-municipalities -regulations-2015-last-amended-on-february-15-2017-_34611.html.

13. Of the 3,700 ULBs in India, only 55 ULBs received investment grade ratings in 2017 (Vinod Kothari Consultants P. Ltd. 2019).

14. The total bond market (sovereign and corporate) is about 15 percent of GDP in 2016, with the sovereign debt dominating while the corporate bonds accounted for only 2.3 percent of GDP (World Bank 2016a). While the total size of the sovereign and corporate bond market increased to about 19 percent of GDP in 2019 (author's calculation), the basic trend of structure has not changed much, with the corporate bond market remaining small, accounting for 3 percent of GDP at the end of 2018: Asiamoney.www.asiamoney.com (accessed 25 November 2019).

15. Asiamoney: www.asiamoney.com (accessed 25 November 2019).

16. Indonesia's decentralization process was guided by two laws which became effective in 2001: Law 22/1999 concerning Subnational Government (regulating political and administrative/governance arrangements) and Law 25/1999 concerning Fiscal Balance between the Central and Subnational Government (regulating fiscal/intergovernmental arrangements).

17. 2015 data are based on World Bank (2016a); and 2019 data calculated by author from various sources: Asiamoney: www.asiamoney.com (accessed 25 November 2019).

18. Information on loan maturities is not available, but based on the author's field work, commercial banks have shorter maturities due to the limitation of the liabilities on their balance sheet.

19. This section draws from Liu and Qiao (2013a), Liu (2011), and the author's field work including discussions with the authorities, faculty at the China Academy of Public Finance and Policy of Central University of Finance and Economics in Beijing, rating agencies, and investors.

20. For 2019, the National People's Congress approves debt outstanding below the ceiling of CNY24.08 trillion. 
21. The annual budget surplus of the LGUs averaged 0.59 percent of GDP from 2009 to 2016: https:// blgf.gov.ph/lgu-fiscal-data/ (accessed December 2020). LGU debt as a percentage of GDP has been about 1 percent or less of GDP (data up to 30 June 2019, calculated from Government of the Philippines, Department of Budget and Management, Bureau of Local Government Finance: https:// blgf.gov.ph/lgu-debt-data/ (accessed December 2020).

22. Data calculated from the Government of the Philippines, Department of Budget and Management, Bureau of Local Government Finance: https://blgf.gov.ph/lgu-debt-data/ (accessed December 2020).

23. In Government of the Philippines. Republic Act No. 7160. An Act Providing For A Local Government Code of 1991. Approved 10 October 1991. Manila.

24. For a summary of the Philippine Water Revolving Fund, which was closed in 2017, see World Bank (2016b).

25. The discussion on the Philippines prior to 2013 draws from Liu et al. (2013b). The development since 2013 draws from the author's discussion with Gilberto Llanto, a trustee of the Philippine Institute for Development Studies.

26. Data calculated from the Government of the Philippines, Department of Budget and Management, Bureau of Local Government Finance.

27. SEBI: Securities and Exchange Board of India (Issue and Listing of Debt Securities by Municipalities) (Amendment) Regulations, 2019. Accessed at: https://www.sebi.gov.in/legal/ regulations/sep-2019/securities-and-exchange-board-of-india-issue-and-listing-of-debt-securities -by-municipalities-amendment-regulations-2019 44519.html.

28. This section on the regulatory framework in Indonesia draws from the author's field work and World Bank (2016a). Regulations prior to Law 23/2014, relevant to subnational borrowing include Government Regulation No. 30/2011 on Regional Borrowings; Regulation of the Minister of Finance of the Republic of Indonesia Number 111/PMK.07/2012 Concerning Procedures for the Issuance and Accountability of Regional Bond; Indonesia Stock Exchange (IDX) Regulation No. 1.F.3 Concerning Listing of Municipal Bonds; and OJK guidelines on documents required for regional bonds.

29. PT SMI - PT Sarana Multi Infrastruktur (Persero) - is a special purpose vehicle established in 2009 under the Ministry of Finance for financing infrastructure projects.

30. A sukuk is a sharia-compliant bond-like instrument used in Islamic finance.

31. This section draws from the author's field work including discussions with the authorities, faculty at the China Academy of Public Finance and Policy of Central University of Finance and Economics in Beijing, rating agencies, and investors.

32. This section draws from Liu et al. (2013b), with data update from the Government of the Philippines, Department of Budget and Management, Bureau of Local Government Finance. The development since 2013 draws on the author's discussion with Gilberto Llanto, a trustee of the Philippine Institute for Development Studies.

33. The latest data are available for November 2020 (at the time this chapter was written in December 2020), from Government of the Philippines, Department of Budget and Management, Bureau of Local Government Finance.

34. The intergovernmental fiscal systems, or more broadly the intergovernmental systems in which fiscal relations are part of the systems, impact subnational finance profoundly. The focus here is on a narrower set of questions that are linked to debt financing. A broader discussion is beyond the scope of this chapter.

35. See Liu and Pradelli (2012) for a review of research on thresholds.

36. For discussion on challenges of developing insolvency systems, see Liu and Waibel (2008a). For discussion on fiscal rules in the broader context of institutions, see Liu and Webb (2011). For the development of Chapter 9 of the US Bankruptcy Code for municipalities, in the overall context of the regulatory frameworks, see De Angelis and Tian (2013), Leigland and Liu (2013), and Liu et al. (2013a).

37. For more details, see Ianchovichina et al. (2007).

38. Data for 2005-2008 are from the Federal Reserve Board. The 2009 data are from Thomson Reuters. The share has been more or less the same since the 1970s. 
39. More than 20,000 municipalities have fewer than 500 inhabitants, and 32,000 municipalities have less than 2,000 inhabitants (for more on SEMs, see Liu et al. 2013c).

40. Based on Fitch's ratings of 13 French SNGs in 2008. Fitch Ratings: https://www.fitchratings.com/ (accessed February 2008) and compilation of various reports.

41. Land transactions in cities such as Cairo, Cape Town, Istanbul and Mumbai, each generated revenues much greater than the respective city's prior annual capital spending. For example, an auction of 13 hectares of land in Mumbai's new financial center in 2006 and 2007 by the Mumbai Metropolitan Regional Development Authority (MMRDA) generated $\$ 1.2$ billion to primarily finance transport projects. The proceeds are 10 times MMRDA's total capital spending in fiscal year 2005. SNGs in the PRC have used land-asset instruments in financing large-scale urban infrastructure investments. See Peterson and Kaganova (2010).

42. For growing state pension liabilities in the US, see the US Government Accountability Office (2010), and The Pew Charitable Trusts (2019).

\section{REFERENCES}

Asian Development Bank (ADB). 2017. Meeting Asia's Infrastructure Needs. Manila.

Canuto, O. and L. Liu. 2010. Subnational Debt Finance and the Global Financial Crisis. Economic Premise. No. 13. Washington, DC: World Bank. Accessed at: https://openknowledge.worldbank.org/ handle/10986/10186.

Canuto, O. and L. Liu (eds) 2013. Until Debt Do Us Part: Subnational Debt, Insolvency, and Markets. Washington, DC: World Bank.

De Angelis, M. and X. Tian. 2013. United States: Chapter 9 Municipal Bankruptcy - Utilization, Avoidance, and Impact. In O. Canuto and L. Liu (eds), Until Debt Do Us Part. pp. 311-51. Washington, DC: World Bank.

Diokno-Sicat, J. and R.B. Maddawin. 2018. A Survey of Literature on Philippines Decentralization. Quezon City: Philippine Institute for Development Studies.

Engel, E., R. Fischer and A. Galetovic. 2009. Public-Private Partnerships: When and How. New Haven: Yale University.

Government of India. 2004. Report of the Twelfth Finance Commission. New Delhi.

Ianchovichina, E. and L. Liu. 2008. Subnational Fiscal Sustainability Analysis. PREM Note 117. Washington, DC: World Bank.

Ianchovichina, E., L. Liu and M. Nagarajan. 2007. Subnational Fiscal Sustainability Analysis: What Can We Learn from Tamil Nadu? Economic \& Political Weekly. 42(52), December.

Leigland, J. and L. Liu. 2013. When Subnational Debt Issuers Default: The Case of the Washington Public Power Supply. In O. Canuto and L. Liu (eds), Until Debt Do Us Part. pp. 353-75. Washington, DC: World Bank.

Liu, L. 2011. Subnational Debt Finance and Risk Management - International Experience. Washington, DC: World Bank.

Liu, L. and G. Peteri. 2015. Global Financial Crisis and Subnational Finance in ECA Region - The Experience of Hungary. Washington, DC: World Bank.

Liu, L. and J. Pradelli. 2012. Financing Infrastructure and Monitoring Fiscal Risks at Subnational Level. Policy Research Working Paper. No. 6069. Washington, DC: World Bank.

Liu, L. and B. Qiao. 2013a. Transition from Direct Central Government Onlending to Subnational Market Access in China. In O. Canuto and L. Liu (eds), Until Debt Do Us Part. pp. 379-416. Washington, DC: World Bank.

Liu, L. and B. Qiao. 2013b. Restructuring of Legacy Debt for Financing Rural Schools in China. In O. Canuto and L. Liu (eds), Until Debt Do Us Part. pp. 81-107. Washington, DC: World Bank.

Liu, L. and K.S. Tan. 2009. Subnational Credit Ratings: A Comparative Review. Policy Research Working Paper. No. 5013. Washington, DC: World Bank.

Liu, L. and M. Waibel. 2008a. Subnational Insolvency: Cross-Country Experiences and Lessons. Policy Research Working Paper. No. 4496. Washington, DC: World Bank.

Liu, L. and M. Waibel. 2008b. Subnational Borrowing, Insolvency and Regulations. In A. Shah (ed.), Macro Federalism and Local Finance. Washington, DC: World Bank, pp. 215-41. 
Liu, L. and S. Webb. 2011. Law for Fiscal Responsibility for Subnational Discipline: International Experience. Policy Research Working Paper. No. 5587. Washington, DC: World Bank.

Liu, L., M. De Angelis and S. Torbert. 2017. Municipal Pooled Financing of Infrastructure in US Experience and Lessons. Policy Research Working Paper. No. 8212. Washington, DC: World Bank.

Liu, L., N. Gaillard and M. Waibel. 2013c. France's Subnational Insolvency Framework. In O. Canuto and L. Liu (eds), Until Debt Do Us Part. pp. 221-59. Washington, DC: The World Bank.

Liu, L., G. Llanto and J. Petersen. 2013b. The Philippines: Recent Developments in the Subnational Government Debt Markets. In O. Canuto and L. Liu (eds), Until Debt Do Us Part. pp. 417-54. Washington, DC: The World Bank.

Liu, L., X. Tian and J.J. Wallis. 2013a. Caveat Creators: State Systems of Local Government Borrowing in the United States. In O. Canuto and L. Liu (eds), Until Debt Do Us Part. pp. 539-90. Washington, DC: World Bank.

Moody's Investors Service. 2018. Rating Methodology Regional and Local Governments. January 16. Accessed at: https://www.moodys.com/researchdocumentcontentpage.aspx?docid=PBC_147779.

Peterson, G.E. and O. Kaganova. 2010. Integrating Land Financing into Subnational Fiscal Management. Economic Policy and Debt Department Draft Paper. Washington, DC: World Bank.

The Pew Charitable Trusts. 2019. The State Pension Debt Funding Gap. Washington, DC.

Rangarajan, C. and A. Prasad. 2013. Managing State Debt and Ensuring Solvency: The Indian Experience. In L. Liu and O. Canuto (eds), Until Debt Do Us Part. pp. 109-44. Washington, DC: World Bank.

State Council of China. 2014. Opinion on Strengthening the Management of Local Government Debt. No. 43. September. Beijing.

United States Government Accountability Office. 2010. State and Local Governments' Fiscal Outlooks. Washington, DC. March.

Vinod Kothari Consultants P. Ltd. 2019. Municipal Bonds in India: An Idea Whose Time Has Come. New Delhi. Accessed at: http://vinodkothari.com/wp-content/uploads/2019/11/Municipal-Bonds_Way -Forward.pdf.

World Bank. 2016a. Indonesia Municipal Bonds Initiative. May. Washington, DC.

World Bank. 2016b. Water Revolving Fund in the Philippines. August. Washington, DC. 